prof. dr hab. Eugeniusz NIEDZIELSKI

Wydział Nauk Ekonomicznych, Uniwersytet Warmińsko-Mazurski w Olsztynie

e-mail: koiz@uwm.edu.pl

\title{
ŹRÓDŁA I POZIOM SATYSFAKCJI Z PRACY W INSTYTUCJI ADMINISTRACJI PUBLICZNEJ NA PRZYKŁADZIE ODDZIAŁU WOJEWÓDZKIEGO ZUS
}

\begin{abstract}
Streszczenie
W artykule przedstawiono wyniki badań dotyczacych źródeł i poziomu satysfakcji z pracy oraz jej wpływu na zmotywowanie pracowników w kontekście utożsamiania się z celami organizacji oraz zadaniami pracowniczymi. Badania wykazały względnie wysoki poziom zadowolenia z pracy, który jest obniżany przez: niski poziom wynagrodzeń, brak uznania ze strony pracodawcy, niekorzystny wizerunek organizacji.
\end{abstract}

Słowa kluczowe: administracja publiczna, satysfakcja z pracy, jakość usług

\section{SOURCES AND LEVELS OF JOB SATISFACTION IN PUBLIC ADMINISTRATION INSTITUTIONS: THE CASE OF PROVINCIAL BRANCH OF ZUS}

\section{Summary}

The paper presents the results of research on the sources and levels of job satisfaction and its impact on the motivation of employees in terms of their identification with their organisation's goals and staff tasks. Studies have shown a relatively high level of job a negative image of the organisation.

Key words: public administration, job satisfaction, service quality

JEL: M120

\section{Wstęp}

Stopień zmotywowania pracowników, powiązany z poziomem satysfakcji z pracy, istotnie wpływa na realizację celów każdej organizacji. Dotyczy to zarówno organizacji biznesowych (przedsiębiorstw), jak i organizacji non profit, do których należą również urzędy administracji rządowej i samorządowej. Jakość usług świadczonych przez instytucje administracji publicznej bezpośrednio i pośrednio wpływa na dobrostan życia: społeczności lokalnych, poszczególnych obywateli i społeczeństwa jako całości. W usługach administracji publicznej klient/obywatel nie ma możliwości wyboru dostawcy usług, 
a tym samym usługodawca nie ma problemu z jego lojalnościa, co jest istotą konkurencyjności w sektorach biznesowych. Niezależnie od tego, czy klient/obywatel odczuwa satysfakcję, czy niezadowolenie z kontaktów z urzędem administracji rządowej lub samorządowej, terytorialnie jest przypisany do korzystania z usług tej, a nie innej instytucji. Być może rozwój technik informatycznych i e-administracji uwolni obywateli od tych ograniczeń i zlikwiduje „przypisanie do ziemi”, ale póki co nie ma możliwości wyboru, a tym samym konkurowania urzędów o klientów. W doskonaleniu jakości usług administracyjnych nie chodzi więc o lojalność obywateli, a o troskę o dobrostan ich życia.

Satysfakcja klienta, rozumiana jako pozytywne odczucie klienta w związku z wartościa jaką otrzymał jako rezultat korzystania z określonej usługi, w dużej mierze zależy od zmotywowania pracowników administracyjnych, będącego pochodną ich satysfakcji z pracy. Wyniki badań prezentowane w literaturze wykazują, że na decyzje o podjęciu zatrudnienia w administracji państwowej maja wpływ takie czynniki, jak: względna stabilność zatrudnienia, unormowany czas pracy i tryb życia, możliwość rozwoju zawodowego i osobistego, prestiż pracy w urzędzie (zwłaszcza w regionach o dużym bezrobociu), gwarantowane świadczenia socjalne [http://piotrlenik.pl (data wejścia: 22.04.2016)]. Zatem bezpieczeństwo zatrudnienia i jego pochodne sa podstawowym źródłem motywacji pracowników, które wynika z istoty pracy, a nie z działań kierownictwa. Zasadniczo różnicowanie oddziaływań motywacyjnych w urzędach administracji jest niezmiernie ograniczone ze względu na bardzo sformalizowane procedury dotyczące: wyznaczenia i realizacji zadań, organizacji pracy, wyodrębniania stanowisk, systemów wynagrodzeń, zależności hierarchicznych itp. [Białas, Litwin, 2013, s. 312]. Ważne są więc te elementy środowiska pracy, które wiążą się z jego miękkimi elementami, takimi jak: styl kierowania, klimat organizacyjny, komunikacja wewnątrzorganizacyjna, możliwości rozwoju, techniczne warunki pracy. Uogólniając, można stwierdzić, że na zmotywowanie i satysfakcję z pracy w urzędzie wpływa zgodność samej istoty pracy z oczekiwaniami pracownika oraz kultura organizacyjna występująca w danej instytucji.

W metodzie Servquel, stosowanej w ocenie usług administracyjnych, uwzględnia się obszary oceny ujęte w następujące grupy:

- materialność usług, obejmująca: wizerunek usługodawcy, warunki lokalowe i wyposażenie, zewnętrzne cechy personelu (np. ubiór);

- solidność, odnoszącą się do terminowości i niezawodności usług czy kompetencji personelu;

- pewność, przejawiająca się we wzbudzaniu zaufania, uprzejmości i wiarygodności;

- empatia, wyrażająca się w umiejętności zrozumienia oczekiwań i potrzeb klienta bądź zainteresowaniu klientem;

- zdolność reagowania, polegająca na udzielaniu klientowi natychmiastowej pomocy, szybkości reagowania na oczekiwania [Mruk, 2012, s. 148].

Poza pierwszym obszarem oceny, pozostałe sa zależne od kompetencji i postaw personelu, o tych zaś decyduje jego zmotywowanie i stopień satysfakcji z pracy, co przekłada się na utożsamianie się pracowników z celami organizacji i w efekcie na satysfakcję klienta. 
Celem badań prezentowanych w niniejszym opracowaniu była identyfikacja oraz hierarchizacja czynników motywacyjnych, a także ocena źródeł i poziomu satysfakcji $\mathrm{z}$ pracy w instytucji administracji państwowej. Anonimowe badania ankietowe przeprowadzono w jednym z oddziałów Wojewódzkich Zakładów Ubezpieczeń Społecznych, wśród 99 pracowników. Pytania ankietowe dotyczyły: samooceny satysfakcji z pracy, identyfikacji z zakładem pracy oraz oceny swych kompetencji i ich wykorzystania. Badania przeprowadzono pod koniec 2015 roku. Próba badawcza stanowiła 14\% osób zatrudnionych w oddziale. Wśród respondentów byli pracownicy z różnym stażem pracy. Wśród nich najwięcej (31\%) było osób ze stażem ponad dwudziestoletnim, jak również osób z wykształceniem wyższym (67\%). Stanowiska kierownicze zajmowało 11 osób. Zakład Ubezpieczeń Społecznych jest bardzo dużą instytucją zatrudniająca w skali kraju około 46 tys. pracowników w centrali, 43 w oddziałach wojewódzkich, 212 w inspektoratach powiatowych i $70 \mathrm{w}$ biurach terenowych. Instytucja ta realizuje niezmiernie ważne społecznie funkcje, będące następstwem obowiązku ubezpieczeń społecznych. Są to nie tylko zadania zwiazane z gromadzeniem środków i wypłatą świadczeń emerytalno-rentowych, choć z tymi powszechnie kojarzy się tę organizację. Świadczy ona usługi klientom, którzy z racji: wieku, stanu zdrowia lub zdarzeń losowych znajdują się w trudnych sytuacjach życiowych. Kontakt $z$ tą organizacją jest często przypadkowy i towarzyszą mu emocje wynikające z: braku znajomości regulacji prawnych i procedur, presji sytuacji życiowej, wieku, stanu zdrowia, braku pewności swoich praw itp. Z tego względu jakość usług, która jest rezultatem nie tylko kompetencji personelu, ale także poziomu zmotywowania i satysfakcji z pracy, ma istotne znaczenie dla klientów tej organizacji. Zachowania w miejscu pracy, które są konsekwencją satysfakcji z pracy bądź jej braku, znajdują odzwierciedlenie w efektach pracy.

Liczne badania, w szczególności prowadzone w przedsiębiorstwach usługowych, gdzie występuje bezpośredni kontakt z klientem, dowiodły, że satysfakcja z pracy jest ważnym kreatorem zachowań wykraczającym poza formalne wymagania na danym stanowisku pracy, w tym: altruizm, zaangażowanie w pracę, przywiązanie do organizacji, indywidualna inicjatywa, sumienność, wytrwałość itp. Brak satysfakcji wpływa na występowanie zachowań obniżających normy organizacyjne, takich jak: absencja, marnotrawienie czasu pracy, defraudacje, oszustwa, niska jakość pracy, zdrowie psychiczne i fizyczne [Bednarska, 2016, s. 100]. Pracownicy, którzy postrzegają swoje środowisko pracy jako satysfakcjonujące, wykazują dużą lojalność i wydajność, a ich postawy i zachowania pozytywnie oddziałują na satysfakcję nabywców [Nieżurawski, Witkowska, 2007, s. 20; Stoma, 2012, s. 313]. Na satysfakcję z pracy składają się trzy aspekty, tj.: ogólna ocena pracy, przekonania na temat pracy oraz doświadczenia emocjonalne związane z pracą [Kulikowski, 2016, s. 81]. Ocena satysfakcji z pracy, jako przejaw subiektywnych odczuć pracowniczych, może być ważnym narzędziem doskonalenia zarządzania zasobami ludzkimi [Drozdowski, 2013, s. 76]. Pozytywne emocje i zadowolenie są pochodną już odnoszonych sukcesów, ale również podstawą do następnych sukcesów zawodowych i życiowych. Zadowolony pracownik cechuje się wyrozumiałością i większą uprzejmością dla wspólpracowników i klientów. Zadowolenie z pracy pozytywnie wpływa na kreatywność i optymizm oraz otwartość w kontaktach z innymi osobami [Kulikowski, 
2016, s. 84]. Znaczenie zmotywowania pracowników i ich satysfakcji z pracy w realizacji celów każdej organizacji, w tym tak ważnej w realizacji celów społecznych, jakim jest Zakład Ubezpieczeń Społecznych, było przesłanką podjęcia badań prezentowanych w niniejszym opracowaniu.

\section{2. Źródła satysfakcji z pracy}

Satysfakcja z pracy jest kształtowana zarówno przez czynniki obiektywne (sytuacyjne), jak i subiektywne (indywidualne). Pierwsza grupę czynników tworza pracodawcy, druga natomiast zależy od indywidualnej percepcji środowiska pracy przez poszczególnych pracowników. Czynniki obiektywne obejmują treść pracy i warunki jej wykonywania. Subiektywna ocena, będąca źródłem satysfakcji, dotyczy: zgodności istoty pracy z preferencjami pracownika, różnorodności lub monotonności zadań, możliwości wykorzystania kompetencji, zakresu samodzielności (doświadczenia wpływu), prestiżu zawodu. Te źródła mogą być wspomagane przez ocenę zewnętrznych korzyści, takich jak: stabilność zatrudnienia i stałość warunków zatrudnienia, wysokość wynagrodzenia, możliwość rozwoju, możliwość awansu, relacje interpersonalne, świadczenia socjalne [Celik, 2011, s. 9; Borowska-Pietrzak, 2014, s. 9-22]. Zdecydowana większość respondentów (65\%) stwierdziła, że jest zadowolona z pracy w badanej instytucji. Ogólne zadowolenie z pracy w ZUS, w skali pięciostopniowej ${ }^{1}$ zostało ocenione na poziomie 3,65 pkt. (tabela 1.). Zadowolenie z pracy jest następstwem oddziaływania takich czynników, jak: stabilność zatrudnienia, terminowa wypłata wynagrodzeń, ruchomy czas pracy, szereg profitów pozapłacowych. Pracownikom odpowiada także usystematyzowany tryb i charakter zadań. Ważna jest również możliwość rozwoju zawodowego, która wyraża się w dostępie do szkoleń odpowiadających potrzebom pracowników. Jednocześnie pozytywnie postrzega się obieg informacji wewnątrzorganizacyjnej oraz dobre relacje ze współpracownikami. Dobry klimat organizacyjny ułatwia przezwyciężanie trudności i radzenie sobie ze stresem wynikającym z presji czasu lub emocji powodowanych złożonościa problemów czy konfliktowymi zachowaniami klientów albo okresowym przeciążeniem praca. Dobra współpraca w zespole jest zarazem ważna w kontekście radzenia sobie ze złożonością i zmiennością regulacji prawnych. Równocześnie przez respondentów pozytywnie są oceniane materialne warunki pracy, w tym: warunki lokalowe, wyposażenie stanowisk, programy informatyczne. Mimo ogólnie wysokiego poziomu zadowolenia z pracy, jedynie co czwarty respondent $(28 \%)$ nie wstydził się mówić, że pracuje w ZUS. Wynika to zapewne z niekorzystnego społecznie wizerunku tej instytucji. Z badań przeprowadzonych przez CBOS wynika, że działalność ZUS jest źle oceniana społecznie, a tylko nieliczne osoby wyrażają pozytywne opinie [http://www.cbos.pl (data wejścia: 27.05.2016)].

Badania wykazały umiarkowany wpływ zadowolenia z pracy na lojalność pracowników, bowiem jedna trzecia respondentów chętnie zmieniłaby pracę, gdyby pojawiła

\footnotetext{
${ }^{1}$ W skali: zdecydowanie nie -1 pkt., raczej nie -2 pkt., brak zdania -3 pkt., raczej tak -4 pkt., zdecydowanie tak -5 pkt.
} 
się taka możliwość. Dotyczyło to zwłaszcza pracowników ze średnim stażem pracy. Natomiast najbardziej zadowoleni i najbardziej lojalni byli pracownicy ze stażem pracy w ZUS powyżej 20 lat.

TABELA 1.

\section{Poziom satysfakcji z pracy badanych osób}

\begin{tabular}{|l|c|c|c|}
\hline \multicolumn{1}{|c|}{ Czynnik wpływający na satysfakcję } & $\begin{array}{c}\text { Osoby na sta- } \\
\text { nowiskach } \\
\text { kierowni- } \\
\text { czych } \\
\mathbf{N = 1 1}\end{array}$ & $\begin{array}{c}\text { Osoby na sta- } \\
\text { nowiskach } \\
\text { niekierowni- } \\
\text { czych } \\
\mathbf{N = 8 8}\end{array}$ & $\begin{array}{c}\text { Ogółem } \\
\mathbf{N = 9 9}\end{array}$ \\
\hline $\begin{array}{l}\text { Jestem zadowolony z pracy w instytucji ad- } \\
\text { ministracji państwowej. }\end{array}$ & 4,18 & 3,58 & 3,65 \\
$\begin{array}{l}\text { Dokładnie wiem, gdzie zaczynaja, a gdzie } \\
\text { kończą się moje obowiązki. }\end{array}$ & 3,82 & 3,59 & 3,62 \\
$\begin{array}{l}\text { Tematyka szkoleń jest dostosowana do po- } \\
\text { trzeb pracownika. }\end{array}$ & 3,82 & 3,56 & 3,59 \\
$\begin{array}{l}\text { Wśród pracowników panuja dobre relacje. } \\
\text { Chętnie zmieniłbym miejsce pracy, gdyby to } \\
\text { było możliwe. }\end{array}$ & 3,73 & 3,47 & 3,49 \\
$\begin{array}{l}\text { Zazwyczaj mam wszystkie informacje po- } \\
\text { trzebne do sprawnego wykonywania mo- }\end{array}$ & 3,55 & 3,56 & 3,48 \\
jej pracy. & 3,91 & 3,28 & 3,36 \\
$\begin{array}{l}\text { Jestem zadowolony z warunków pracy } \\
\text { (sprzęt, warunki lokalowe). }\end{array}$ & 3,91 & 3,17 & 3,31 \\
$\begin{array}{l}\text { Mogę tu awansować. } \\
\text { Nie wstydzę się mówić, że pracuję w tej } \\
\text { firmie. }\end{array}$ & 2,45 & 2,89 & 3,25 \\
\hline
\end{tabular}

Źródło: badania własne.

Poziom satysfakcji z pracy jest wyraźnie wyższy wśród osób pełniących funkcje kierownicze niż wśród personelu wykonawczego (tabela 1.). Ta sumaryczna, wysoka ocena jest pochodną wysokiej oceny poszczególnych składowych obszarów oceny.

\section{Postrzeganie zakładu pracy przez pracowników}

Wizerunek wewnętrzny pracodawcy ma duży wpływ na kształtowanie postaw pracowniczych i wizerunku zewnętrznego. Respondenci w większości ocenili, że pracują w dobrej instytucji (3,08 pkt.), choć, ich zdaniem, nie najlepiej zarządzanej (2,66 pkt.) (tabela 2.). Krytyczną ocenę jakości zarządzania wyraziło $41 \%$ badanych pracowników, w tym także część kadry kierowniczej. Opinie te wynikają zapewne z: ograniczonej samodzielności pracowników w wykonywaniu zadań, niedostatecznego doceniania ich pracy oraz z niskiego poziomu płac i niesprawiedliwego przyznawania podwyżek. Badania uniemożliwiają szczegółową identyfikację obszarów niesprawności zarządzania w odniesieniu do jego poszczególnych funkcji, ti.: planowania, organizowania, motywowania 
i kontrolowania. Uwagi respondentów odnosiły się do niewystarczającej sprawności wykonywania ról kierowniczych przez kadrę zarządzająca.

TABELA 2.

Postrzeganie zakładu pracy przez pracowników

\begin{tabular}{|c|c|c|c|c|c|}
\hline $\begin{array}{l}\text { Czynnik wpły- } \\
\text { wający na po- } \\
\text { strzeganie za- } \\
\text { kładu pracy }\end{array}$ & $\begin{array}{c}\text { Stanowiska } \\
\text { kierownicze } \\
\mathrm{N}=11\end{array}$ & $\begin{array}{c}\text { Stanowiska } \\
\text { niekierowni- } \\
\text { cze } \\
\mathrm{N}=88\end{array}$ & $\begin{array}{c}\text { Pracownicy } \\
\text { z wykształce- } \\
\text { niem średnim } \\
\mathrm{N}=34\end{array}$ & $\begin{array}{c}\text { Pracownicy } \\
\text { z wykształ- } \\
\text { ceniem wyż- } \\
\text { szym } \\
N=65\end{array}$ & $\begin{array}{c}\text { Ogółem } \\
\mathrm{N}=99\end{array}$ \\
\hline $\begin{array}{l}\text { Popieram cele mo- } \\
\text { jego zakładu pra- } \\
\text { cy. }\end{array}$ & 3,45 & 3,41 & 3,68 & 3,28 & 3,41 \\
\hline $\begin{array}{l}\text { Wiem co powinie- } \\
\text { nem robić, aby po- } \\
\text { móc zakładowi } \\
\text { pracy w realizacji } \\
\text { celów. }\end{array}$ & 3,45 & 3,30 & 3,26 & 3,34 & 3,27 \\
\hline $\begin{array}{l}\text { Zasady przyzna- } \\
\text { wania świadczeń } \\
\text { socjalnych są spra- } \\
\text { wiedliwe. }\end{array}$ & 3,18 & 0,328 & 3,24 & 3,28 & 3,26 \\
\hline $\begin{array}{l}\text { Przełożeni liczą się } \\
\text { z moim zdaniem. }\end{array}$ & 3,82 & 3,13 & 3,29 & 3,15 & 3,20 \\
\hline $\begin{array}{l}\text { Jestem pracowni- } \\
\text { kiem dobrej insty- } \\
\text { tucji. }\end{array}$ & 3,27 & 3,06 & 3,29 & 2,97 & 3,08 \\
\hline $\begin{array}{l}\text { Mam wplyw na to, } \\
\text { co robię. }\end{array}$ & 2,91 & 2,83 & 2,76 & 2,88 & 2,84 \\
\hline $\begin{array}{l}\text { Instytucja, w której } \\
\text { pracuję, jest dob- } \\
\text { rze zarządzana. }\end{array}$ & 2,91 & 2,63 & 2,85 & 2,55 & 2,66 \\
\hline $\begin{array}{l}\text { Czuję się tu doce- } \\
\text { niany. }\end{array}$ & 3,09 & 2,58 & 2,71 & 2,60 & 2,64 \\
\hline $\begin{array}{l}\text { Zasady przyzna- } \\
\text { wania podwyżek } \\
\text { są sprawiedliwe. }\end{array}$ & 2,64 & 2,28 & 2,47 & 2,25 & 2,32 \\
\hline $\begin{array}{l}\text { Instytucja jest do- } \\
\text { brze postrzegana } \\
\text { przez klientów. }\end{array}$ & 1,82 & 1,98 & 2,09 & 1,89 & 1,96 \\
\hline
\end{tabular}

Źródło: badania własne.

Średnie wynagrodzenie pracowników w badanym oddziale ZUS jest niższe od przeciętnego wynagrodzenia w gospodarce narodowej. Tymczasem zadania realizowane przez tych pracowników wymagaja: szerokiej wiedzy prawniczej, znajomości procedur, zdolności analitycznych oraz umiejętności korzystania z różnych systemów informatycznych. Często towarzyszy temu presja czasu i złożoność sytuacji.

Pracownicy identyfikują się z celami instytucji, w której pracują jednak tylko 40\% respondentów wiedziało, w jaki sposób pomóc zakładowi w realizacji celów. 
Cel strategiczny ZUS zakłada zwiększenie zaufania klientów do tej instytucji. Realizacja tego celu została przypisana poszczególnym komórkom i rozpisana na zadania i procesy. Duża liczba procesów (400) i niepełna wiedza pracowników w zakresie zarządzania procesowego zapewne spowodowała, że część pracowników nie wiedziała, jak przyczyniać się do realizacji tego celu. Pracownicy mieli świadomość, że instytucja nie jest najlepiej postrzegana przez klientów (1,96 pkt.), zatem realizacja celu strategicznego, który ma ten wizerunek poprawić, jest bardzo ważna. Problem polega na świadomym uczestnictwie pracowników w jego realizacji, a to wymaga właściwego obiegu informacji, wyodrębnienia oraz powiązania zadań i procesów bez nadmiernego formalizowania procedur. Korzystniejsze od przeciętnych oceny poszczególnych obszarów postrzegania zakładu pracy wyrażali pracownicy z najkrótszym (do 5 lat) i najdłuższym stażem pracy (powyżej 20 lat) w ZUS. Dotyczyło to: znajomości zadań i wpływu na ich wykonywanie, wysokości wynagrodzenia i zasad jego przyznawania, wspierania celów organizacji i zasad przyznawania świadczeń socjalnych.

\section{Samoocena pracownicza}

Dokonując samooceny, pracownicy wyrażają swoje subiektywne odczucia związane z ocenianymi aspektami pracy zawodowej. Zawyżona lub zaniżona samoocena wpływa na poziom satysfakcji z pracy oraz na relacje ze wspólpracownikami. W prezentowanych badaniach pracownicy dokonywali oceny wykorzystania ich kompetencji i osobistego zaangażowania $\mathrm{w}$ realizację zadań. Oceniano także stosunek do wykonywania pracy przejawiający się w: staranności i sprawności realizowania zadań, kreatywności i zmotywowaniu. Wszyscy respondenci wysoko ocenili swoje kompetencje i zaangażowanie w wykonywana pracę (tabela 3.). Większość z nich (70\%) uznała, że sprawnie, starannie i fachowo wykonuje swoje obowiązi służbowe. Ponad $80 \%$ respondentów jest bardzo zaangażowanych w wykonywanie zadań, mimo niskiego i nieadekwatnego w odniesieniu do wykonywanej pracy wynagrodzenia. Pewnie, dlatego $60 \%$ z nich chętnie zmieniłaby pracę na mniej interesująca, ale lepiej płatną. Wyniki te dowiodły, że poziom zaangażowania pracowników był w dużym stopniu uzależniony od poziomu wynagrodzeń. Nie wykazały one dużych różnic w samoocenie pracowników, w zależności od wykształcenia i stażu pracy. Wyższą od przeciętnej samoocenę wyraziły osoby zajmujące stanowiska kierownicze, co wydaje się w pełni uzasadnione. Jednocześnie osoby z najdłuższym stażem pracy i z dużym doświadczeniem wysoko oceniły swoje kompetencje $\mathrm{i}$ ich wykorzystanie, to natomiast przekłada się w zaangażowanie w realizację zadań zawodowych. 
TABELA 3.

\section{Samoocena pracownicza w zależności od poziomu wykształcenia pracowników oraz zajmowanego przez nich stanowiska}

\begin{tabular}{|c|c|c|c|c|c|}
\hline $\begin{array}{c}\text { Czynnik podlegający } \\
\text { samoocenie }\end{array}$ & $\begin{array}{c}\text { Stanowis- } \\
\text { ka kierow- } \\
\text { nicze } \\
\mathrm{N}=11\end{array}$ & $\begin{array}{c}\text { Stanowiska } \\
\text { wykonawcze } \\
\mathrm{N}=88\end{array}$ & $\begin{array}{l}\text { Pracownicy } \\
\text { z wykształce- } \\
\text { niem średnim } \\
\quad \mathrm{N}=34\end{array}$ & $\begin{array}{l}\text { Pracownicy } \\
\text { z wykształ- } \\
\text { ceniem wyz- } \\
\text { szym } \\
\mathrm{N}=65\end{array}$ & $\begin{array}{c}\text { Ogółem } \\
\mathbf{N}=99\end{array}$ \\
\hline $\begin{array}{l}\text { Starannie i fachowo ro- } \\
\text { bię to, co do mnie nale- } \\
\text { ży. }\end{array}$ & 4,55 & 4,36 & 4,35 & 4,40 & 4,38 \\
\hline $\begin{array}{l}\text { Chętnie wkładam w pra- } \\
\text { cę więcej wysiłku, niż to } \\
\text { uzasadnia moje wynagro- } \\
\text { dzenie. }\end{array}$ & 4,45 & 4,14 & 4,21 & 4,15 & 4,17 \\
\hline $\begin{array}{l}\text { Sprawnie wykonuję swo- } \\
\text { je obowiązki służbowe. }\end{array}$ & 4,00 & 4,11 & 4,00 & 4,15 & 4,10 \\
\hline $\begin{array}{l}\text { Dobrze znam się na swo- } \\
\text { jej pracy. }\end{array}$ & 4,09 & 4,03 & 4,24 & 3,94 & 4,04 \\
\hline $\begin{array}{l}\text { Wolałbym lepiej płatna } \\
\text { prace, nawet gdyby była } \\
\text { mniej ciekawa. }\end{array}$ & 3,09 & 3,91 & 3,68 & 3,89 & 3,82 \\
\hline $\begin{array}{l}\text { Moja wiedza, umiejętno- } \\
\text { ści i kwalifikacje są w pel- } \\
\text { ni wykorzystywane na } \\
\text { moim stanowisku pra- } \\
\text { cy. }\end{array}$ & 3,82 & 3,55 & 3,68 & 3,52 & 3,58 \\
\hline $\begin{array}{l}\text { Czasami wypróbowuję } \\
\text { jakieś nowe rozwiązania. }\end{array}$ & 3,91 & 3,40 & 3,38 & 3,49 & 3,45 \\
\hline $\begin{array}{l}\text { Czuję się zachęcany do } \\
\text { kreowania nowych i lep- } \\
\text { szych rozwiązań. }\end{array}$ & 3,73 & 2,95 & 3,06 & 3,03 & 3,04 \\
\hline
\end{tabular}

Źródło: badania własne.

\section{Podsumowanie}

Wyniki badań wykazały, iż pracownicy badanej instytucji w większości są zadowoleni z pracy. Ogólny wskaźnik poziomu satysfakcji w skali pięciopunktowej ukształtował się na poziomie 3,4 pkt. Na względnie wysoki poziom zadowolenia wpływaja zwłaszcza takie czynniki, jak: elastyczny czas pracy, terminowa wypłata wynagrodzeń, ośmiogodzinny czas pracy, szeroki zakres świadczeń pozapłacowych i socjalnych. Na ogólne zadowolenie z pracy w ZUS najbardziej oddziałują trzy czynniki, a mianowicie: wyraźne określenie zakresu obowiązków i dobra organizacja pracy, dostęp do szkoleń i możliwość rozwoju oraz dobra atmosfera w pracy (klimat organizacyjny). Poziom satysfakcji z pracy w badanej instytucji obniżaja głównie takie czynniki, jak: niskie wynagrodzenia, brak uznania ze strony pracodawcy, a także niekorzystny wizerunek organizacji. Brak zmian w polityce płacowej może spowodować, że wielu kompetentnych pracowników będzie poszukiwało nowego pracodawcy. Świadczą o tym wyniki badań dotyczące lojalności 
pracowniczej. Badani pracownicy bardzo wysoko ocenili swój poziom kompetencji i sprawności pracowniczej. Wiązało się to z tym, że duża część pracowników posiadała długi staż pracy w ZUS, a tym samym duże doświadczenie zawodowe. Ważne jest zatem zapewnienie ich lojalności m.in. dzięki wyeliminowaniu czynników obniżających poziom ich satysfakcji z pracy w badanej instytucji. Sprawność pracownicza, zaangażowanie w realizację zadań przy wysokich kompetencjach pracowników będzie pozytywnie wpływać na satysfakcję klientów, a co za tym idzie, na poprawę wizerunku organizacji. Warunkiem spełnienia tych oczekiwań jest poprawa umiejętności zarządzania i pełnienia ról kierowniczych. Wysoka samoocena kadry kierowniczej nie znajduje bowiem pełnego uzasadnienia w opiniach personelu wykonawczego.

\section{Literatura}

Bednarska M., 2016, Satysfakcja zpracy i jej wplyw na lojalność wobec pracodawcy, Studium Sektora HORECA, „Organizacja i Kierowanie”, nr 1.

Białas S., Litwin J., 2013, Poziom satysfakcji z.pracy pracowników administracji publicznej na prayketadzie Urzedu X, Zeszyty Naukowe Uniwersytetu Przyrodniczo-Humanistycznego w Siedlcach, nr 24(97), Siedlce.

Borowska-Pietrzak A., 2014, Dezagregacja czynnikón w modelu poczucia satysfakcji zawodowej, „Nauki o Zarządzaniu”, nr 1 (18).

Celik M., 2011, A theoretical aproach to the job satisfaction, "Polish Journal of Management Studies", vol. 4.

Drozdowski G., 2013, Motywowanie pracowników w organizacjach publicznych, t. IX, Zeszyty Naukowe Państwowej Wyższej Szkoły Zawodowej w Sulechowie, Sulechów. http://www.cbos.pl (data wejścia: 27.05.2016).

http://piotrlenik.pl (data wejścia: 22.04.2016).

Kulikowski K., 2016, Wykoryystanie wskaźnikón satysfakciji z pracy w procesie zarzadzania ludżmi - zarys problemu i propozycja naržedzia badawczego, „Organizacja i Kierowanie”, nr 1.

Mruk H., 2012, Marketing. Satysfakecja klienta i rozwoój przęsiebiorstwa, Wydawnictwo Naukowe PWN, Warszawa.

Nieżurawski L., Witkowska J., 2007, Pojecie satysfakcï klienta, „Problemy Jakości”, nr 7.

Stoma M., 2012, Modele i metody pomiaru jakości ustug, Q\&R, Lublin. 